\title{
MAJOR AND TRACE ELEMENTS COMPOSITION OF CR-DIOPSIDES FROM THE ZAGADOCHNAYA KIMBERLITE PIPE (YAKUTIA, RUSSIA): INSIGHTS INTO METASOMATIC PROCESSES IN THE YAKUTIAN LITHOSPHERE
}

\author{
Isabel Dencker ${ }^{1}$, Paolo Nimis ${ }^{1}$, Alberto Zanetti ${ }^{2}$ and Nikolay V. Sobolev ${ }^{3}$ \\ ${ }^{I}$ University of Padova, Italy; ${ }^{2}$ CNR-IGG Pavia, Italy; ${ }^{3}$ Institute of Mineralogy and Petrology, RAS Novosibirsk, Russia
}

\section{INTRODUCTION}

The Zagadochnaya pipe is situated in the Siberian craton of Yakutia (Russia), $30 \mathrm{~km} \mathrm{SW}$ of the wellknown diamondiferous Udachnaya pipe. Despite this small distance between the two kimberlite pipes the Zagadochnaya pipe is free of diamonds. Compared with diamondiferous kimberlite pipes of Yakutia, the Zagadochnaya kimberlite is also distinct by the absence of discrete peridotitic xenoliths and high abundance of kyanite-eclogitic and especially grospyditic xenoliths (Bobrievich et al., 1960; Sobolev et al., 1968). The reason why some closely occurring kimberlite pipes can be so different in terms of xenolith load and diamond productivity is still a matter of debate.

To explore the potential differences in mantle processes among different portions of the Yakutian lithosphere, we have studied chromian diopsides and chromian pyropes from coarse mineral concentrates from the Zagadochnaya kimberlite and have compared them with literature data on Udachnaya analogues.

\section{ANALYTICAL METHODS}

Diopsides and pyropes, as well as diopside-bearing polymineralic aggregates were selected from concentrates (1-3 $\mathrm{mm}$ size fraction) of the Zagadochnaya kimberlite. The grains were mounted on epoxy resin, cut to about half their thickness and polished for chemical analysis. Major elements were analyzed through a WDS-electron microprobe at the Dipartimento di Mineralogia e Petrologia, University of Padova, Italy. Trace elements were analyzed through LA-ICP-MS at the CNR-IGG, Section of Pavia, Italy.

\section{PETROGRAPHY AND MINERAL CHEMISTRY}

The diopsides occur as rounded grains which can be emerald green to granny-smith green in color. Individual grains may show domains characterized by either colors. The emerald green portions are mostly transparent, whereas the granny-smith ones tend to have a cloudy appearance. Cloudy domains are typically found near veinlets a few microns thick, which consist of phlogopite, colorless glass and diopside. Inclusions of calcite and chromite are common. Small diopside grains are found as inclusions in garnets and within polycrystalline aggregates composed of calcite, phlogopite, andesine and a brownish material (glass ?).
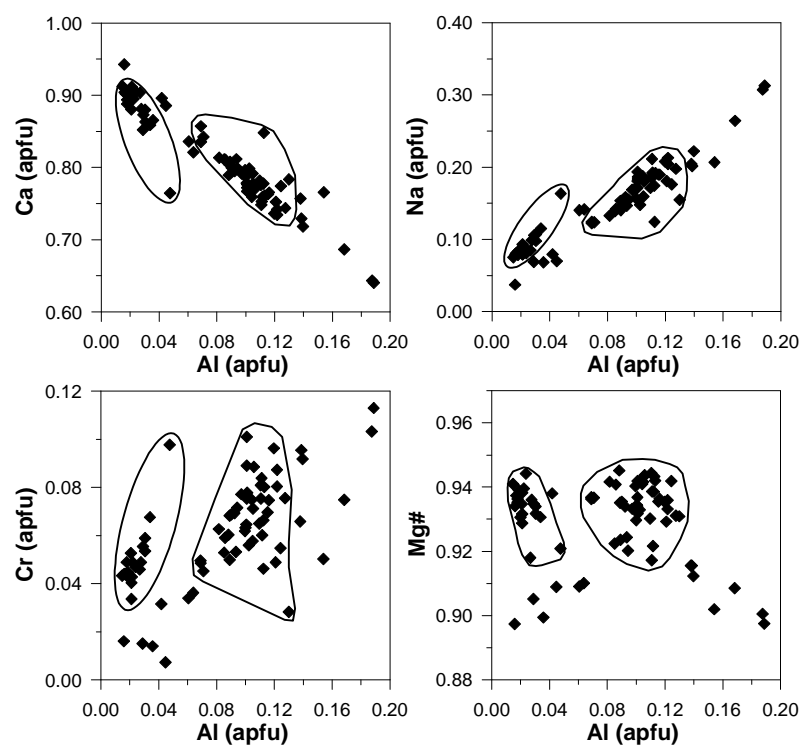

Figure 1: Major elements variations in the studied diopsides with main compositional clusters described in the text.

On the whole, the diopsides are characterized by increasing $\mathrm{Na}, \mathrm{Cr}$ and $\mathrm{Ti}$, and decreasing $\mathrm{Ca}$ with increasing Al. Relations among the different major cations allow us to distinguish at least three main compositional groups (Fig. 1). The groups do not necessarily correspond to distinct grain suites, and transitions between different groups can be found within single grains. A well-defined group of compositions is characterized by low $\mathrm{Al}(<0.05$ apfu) and $\mathrm{Na}$ (mostly $<0.04$ apfu), high $\mathrm{Ca}$ (mostly $>0.85$ apfu), and high $\mathrm{Mg \#}(0.92-0.94)$. This group is also characterized by a pronounced increase of $\mathrm{Cr}(0.04-$ $0.10 \mathrm{apfu}$ ) with increasing Al. This compositional type is typically found in the cloudy grains and in cloudy domains near veinlets cutting transparent diopsides. A second compositional cluster is characterized by higher 
Al (0.07-0.13 apfu) and $\mathrm{Na}(0.12-0.21 \mathrm{apfu})$, lower $\mathrm{Ca}$ (0.73-0.86 apfu), comparable $\mathrm{Mg \#} \mathrm{(0.92-0.94)} \mathrm{and}$ variable $\mathrm{Cr}(0.03-0.10 \mathrm{apfu})$. This group does not show a clear correlation between $\mathrm{Cr}$ and $\mathrm{Al}$. This compositional type is typical of the emerald-green diopsides. Most of the remaining compositions have distinctly lower $\mathrm{Mg} \#(0.90-0.92)$ and span a wide range of $\mathrm{Ca}, \mathrm{Na}, \mathrm{Cr}$ and $\mathrm{Al}$ values, indicating minor to high molar fractions of jadeite (up to 17\%) and kosmochlor (up to $12 \%$ ) components. The most jadeite and kosmochlor-poor compositions were found in veinlethosted diopsides, in inclusion-rich cloudy domains as well as in the polymineralic aggregates. The most jadeite and kosmochlor-rich compositions were found in diopside inclusions in garnet grains.

The garnets are low-CaO (4.6-6.2 wt \%) chromianpyropes $\left(\mathrm{Cr}_{2} \mathrm{O}_{3} 4.3-6.4 \mathrm{wt} \%\right)$. Besides diopside, they contain inclusions of chromian spinel and phlogopite, and show strong chemical similarities to garnets from garnet-peridotite xenoliths found in kimberlites worldwide. The $\mathrm{CaO}$ vs. $\mathrm{Cr}_{2} \mathrm{O}_{3}$ relations suggest a lherzolitic signature (Sobolev et al., 1973).

Phlogopites in veinlets and those included in garnets have low $\mathrm{TiO}_{2}(\sim 0.4 \mathrm{wt} \%)$ and low $\mathrm{Cr}_{2} \mathrm{O}_{3}(0.4-1.1$ wt $\%$ ) contents, comparable with those of primary phlogopites from peridotite xenoliths from South Africa and Udachnaya (e.g. Erlank et al., 1987; Gregoire et al., 2002; Solovjeva et al., 1997). Phlogopites in polycrystalline aggregates attached to or within (?) diopside grains are richer in $\mathrm{TiO}_{2}(\sim 2.7 \mathrm{wt} \%)$ and $\mathrm{Cr}_{2} \mathrm{O}_{3}$ $(\sim 1.4 \mathrm{wt} \%)$. These aggregates are probably analogous to the free aggregates found in the concentrates. Occasional relicts of garnet suggest that these aggregates are the product of reactions between earlier diopside-associated garnets and infiltrating melts, similar to what reported for megacrysts in kimberlites (e.g. Solovjeva et al., 1997).

\section{TRACE ELEMENT COMPOSITIONS OF DIOPSIDES}

Based on trace element data, three main compositional groups (A, B and C) can be distinguished. The distinction into these three groups is corroborated by a broad correspondence between major element compositional clusters and observed trace element patterns.

Group A shows variably enriched, normalized LREE patterns with $(\mathrm{La} / \mathrm{Yb})_{\mathrm{n}}$ in the range $16-730$, strong negative $\mathrm{Zr}$ and $\mathrm{Hf}$ anomalies, and no or slightly
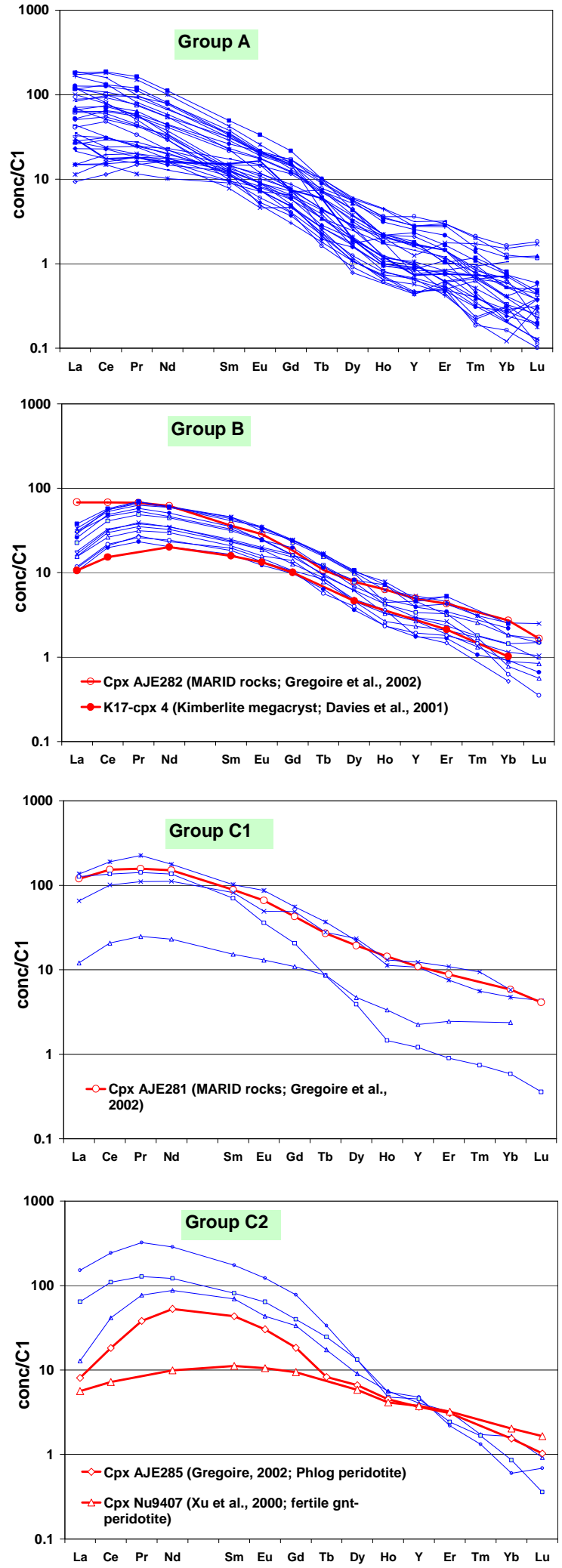

Figure 2: Normalized REE patterns for Zagadochnaya diopsides compared with diopsides from MARID, phlogopite peridotites, fertile garnet peridotite and megacrysts ( $\mathrm{C} 1$ data from Anders and Grevesse, 1989). 
positive or negative Ti anomalies. $\mathrm{Sc} / \mathrm{V}$ ratios are much lesser than unity (Fig. 2a). The most incompatible elements reach very high contents (e.g. $\mathrm{Nb} \sim 10$ ppm; $\mathrm{U}$ $\sim 0.5 \mathrm{ppm})$. These trace element patterns are usually associated with major-element compositions corresponding to the high-( $\mathrm{Al}, \mathrm{Na}, \mathrm{Mg \#})$ compositional type. Group B shows LREE-enriched, convex-upward normalized patterns, with $(\mathrm{La} / \mathrm{Yb})_{\mathrm{n}}$ ratios in the range 11-22, $(\mathrm{La} / \mathrm{Sm})_{\mathrm{n}}$ ratios in the range $0.6-0.9$ and $\mathrm{Pb}$ under detection limit (Fig. 2b). It is characterized by negative $\mathrm{Zr}$ and strongly negative $\mathrm{Ti}$ anomalies, no or slight $\mathrm{Hf}$ and $\mathrm{Sr}$ anomalies and $\mathrm{Sc} / \mathrm{V}$ ratios greater than unity. They show some similarities with diopside megacrysts from kimberlites (e.g. Davies et al., 2001). Group C also shows LREE-enriched, convex-upward patterns, but with very variable $(\mathrm{La} / \mathrm{Yb})_{\mathrm{n}}$ ratios $(5-250)$ (Fig. 2c,d). A subgroup (C1) is characterized by $\mathrm{Mg \#}$ ratios typically lower than 0.92 . It displays moderately to strongly negative $\mathrm{Zr}$, $\mathrm{Hf}$ and $\mathrm{Ti}$ anomalies, and variable REE, Sc and $\mathrm{V}$ contents [with $(\mathrm{Sc} / \mathrm{V})_{\mathrm{n}}$ lower to slightly higher than 1]. One of subgroup-C1 diopsides shows strong similarities with MARID diopsides (cf. Gregoire et al., 2002). Another subgroup (C2), which is characterized by a more pronounced convexity in the LMREE region, nearly constant HREE and $\mathrm{Mg \#}$ greater than 0.92, shows similarities with diopsides from phlogopite peridotites (cf. Gregoire et al., 2002).

\section{DISCUSSION}

\section{ORIGIN OF THE DIOPSIDES}

The high Mg\# values and the strong HREE, Ti, Sc, V depletion of many of the diopsides, especially those belonging to Group A, are consistent with derivation from variably depleted garnet-peridotite sources. In most diopsides, however, $\mathrm{Mg} \#$ ratios exceed the value of 0.92 , which is regarded to be the highest $\mathrm{Mg \#}$ for residual clinopyroxene after partial melting. Very high Mg\# values such as those found in Zagadochnaya diopsides have been interpreted to reflect metasomatic imprints operated by alkaline silicate or carbonatitic melts on previously strongly depleted peridotites (e.g. Yaxley et al., 1991; Wang and Gasparik, 2001).

Group A diopsides with relatively high $\mathrm{Al}, \mathrm{Na}$ and $\mathrm{Cr}$ contents show major-element compositional similarities with diopsides from garnet peridotites (GP) and garnetphlogopite peridotites (GPP) recovered in the Kimberley pipes, South Africa (Erlank et al., 1987), as well as with pyroxenes of metasomatic origin in garnet lherzolite and garnet pyroxenite xenoliths from Udachnaya (Solovjeva et al., 1997). Hypothetical liquids calculated on the basis of ${ }^{\mathrm{Cpx} / \mathrm{L}} \mathrm{D}$ for the most LILE-enriched diopsides are similar to those of alkaline differentiates and/or carbonatitic melts. The variable LILE (Th, U, Sr, LREE) enrichment and fractionation, the variability of the negative $\mathrm{Zr}$ and $\mathrm{Hf}$ anomalies, and the positive correlation between $\mathrm{Na}$ and $\mathrm{Cr}$ can be interpreted to reflect geochemical gradients due to melt-peridotite interaction at decreasing porosity (Yaxley et al., 1991; Vernieres et al., 1997).

Group B diopsides have humped REE patterns consistent with equilibrium with rather primitive alkaline melts. Despite the appreciable variations in absolute trace element concentrations, the inter-element fractionations are nearly constant. Diopsides belonging to this group may represent the product of extensive reactions between mantle peridotites and large volumes of percolating melts, either by continuous melt feeding at the base of the mantle column or through impregnation by a interconnected melt network (e.g. Bodinier et al., 1990; Zanetti et al., 1996; Moine et al., 2001). The large $\mathrm{Sc} / \mathrm{V}$ ratios (greater than unity) suggest that garnet was not a stable phase at the time of mantle-melt reaction (Zanetti, unpublished data). The high $\mathrm{Ca}$ contents also indicate the absence of orthopyroxene in the equilibrium mineral assemblages. These characters are consistent with metasomatic processes under relatively low pressure conditions, perhaps operated by the host kimberlitic magma during transport to surface. This hypothesis would be consistent with the occurrence of these compositions in proximity of glass-bearing veinlets.

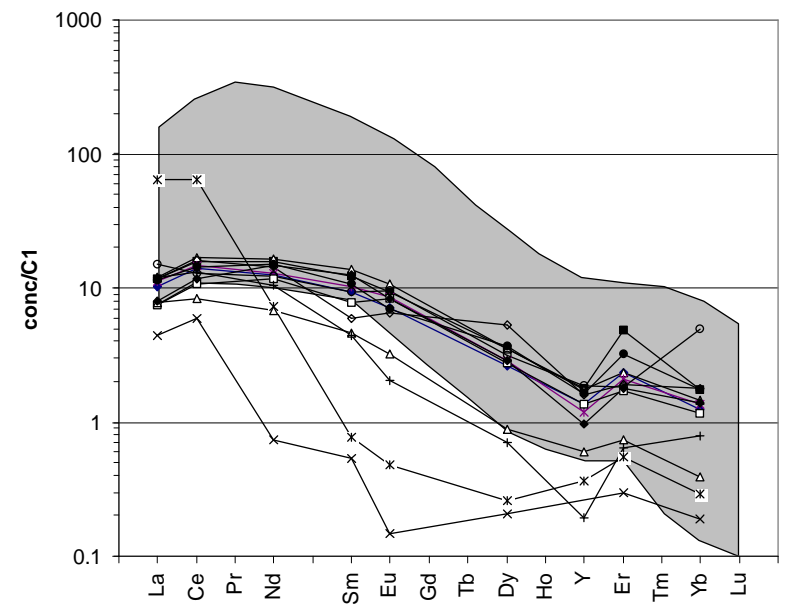

Figure 3: Normalized REE patterns for Udachnaya diopsides (data from Shimizu et al., 1997). The shaded area encompasses the entire range of compositions in the studied Zagadochnaya diopsides. 


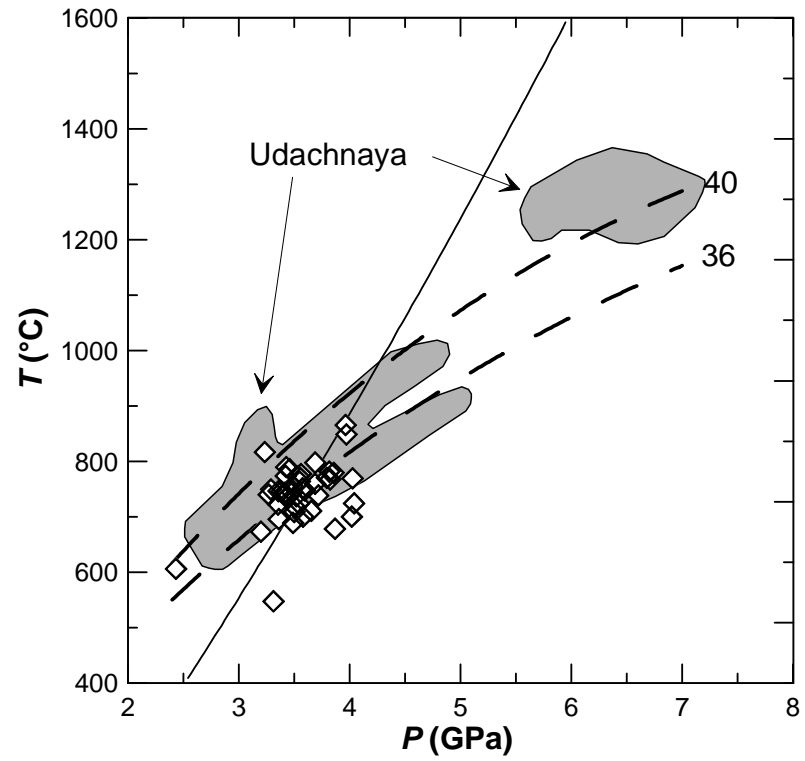

Figure 4: $\mathrm{P}-\mathrm{T}$ estimates for Zagadochnaya diopsides of presumed garnet-peridotite derivation. Fields for Udachnaya diopsides after Nimis (2002).

Group C diopsides also have humped REE patterns, consistent with equilibrium with rather primitive alkaline melts. Some of these diopsides show strict similarities to diopsides from the MARID and phlogopite-peridotite rock suites (cf. Gregoire et al., 2002).

Comparison with trace element data of diopsides from Udachnaya (Shimizu et al., 1997) and Mir (Sobolev et al., 1997) garnet peridotites suggests that, on the whole, Zagadochnaya diopsides underwent a stronger enrichment in highly incompatible elements, indicating a more extensive metasomatism by alkaline silicate and/or carbonatitic melts (Fig. 3).

\section{P-T Estimates}

$\mathrm{P}-\mathrm{T}$ estimates for the Zagadochnaya diopsides that are likely to have derived from a garnet peridotite source [i.e. Group A high-(Na, Al, Cr, Mg\#) compositions] were calculated with the single-Cpx thermobarometers of Nimis and Taylor (2000). The thermobarometers require that the diopsides be in equilibrium with both garnet and orthopyroxene. The calculated $\mathrm{P}-\mathrm{T}$ values broadly overlap those obtained for other Yakutian kimberlites, particularly Udachnaya (Fig. 4). Although some $\mathrm{P}-\mathrm{T}$ points fall within the stability field of diamond, many of them would require unreasonably low geothermal gradients. These anomalous estimates probably reflect disequilibrium of clinopyroxene with garnet and orthopyroxene, possibly related to the documented extensive metasomatism. Leaving these suspicious diopsides out, the bulk of the samples appears to have derived from a restricted pressure region which lies above or just within the diamond window $(<4 \mathrm{GPa})$.

\section{CONCLUSIONS}

The major and trace element study of diopsides from the Zagadochnaya kimberlite pipe indicates that all samples underwent significant metasomatic processes leading to strong enrichments in incompatible elements and in some cases, possibly, chromium. The large variability of major and trace element patterns suggests the occurrence of at least two distinct metasomatic processes, one operated by carbonatitic and/or alkaline silicate melts in the mantle and one possibly related to reactions with the host kimberlite magma during transport to surface. The degrees of the metasomatic enrichment appear to be higher than those recorded by mantle xenoliths from the nearby Udachnaya kimberlite. These peculiar processes and the relatively shallow depth of provenance of diopside-bearing mantle materials in the Zagadochnaya pipe may be envisaged as possible factors that contributed to determine its barren nature. 


\section{REFERENCES}

Anders, E., Grevesse, N., 1989. Abundances of the elements: meteoric and solar. Geochim. Cosmochim. Acta 53, $197-214$

Bobrievich, A.P., Smirnov, G.I., Sobolev, V.S., 1960. Mineralogy of xenoliths of grossular-pyroxenedisthene rock (grospydite) from Yakutian kimberlites. Geologiya i Geofiz. 1, 18-24 (in Russian).

Bodinier, J.-L., Vasseur, G., Vernieres, J., Dupuy, C., Fabries, J., 1990. Mechanisms of mantle metasomatism: geochemical evidence from the Lherz orogenic peridotite. J. Petrol. 31, 597-628.

Davies, G.R., Spriggs, A.J., Nixon, P.H., 2001. A noncognate origin for the Gibeon kimberlite megacryst suite, Namibia: implications for the origin of Namibian kimberlites. J. Petrol. 42, 159-172.

Erlank, A.J., Waters, F.G., Hakesworth, C.J., Haggerty, S.E., Allsopp, H.L., Rickard, R.S., Menzies, M., 1987. Evidence for mantle metasomatism in peridotite nodules from the Kimberley pipes, South Africa. In: Menzies, M.A., Hawksworth, C.J. (Eds.), Mantle Metasomatism. Academic Press, pp. 221-275.

Grégoire, M., Bell, D.R., Le Roex, A.P., 2002. Trace element geochemistry of phlogopite-rich mantle xenoliths: their classification and their relationship to phlogopitebearing peridotites and kimberlites revisited. Contrib. Mineral. Petrol. 142, 603-625.

Moine, B.N., Gregoire, M., O'Reilly, S.Y., Sheppard, S.M.F., Cottin, J.Y., 2001. High Field Strength Element fractionation in the Upper Mantle: Evidence from amphibole-rich composite mantle xenoliths from Kerguelen Islands (Indian Ocean). J. Petrol. 42, 21452167.

Nimis, P., 2002. The pressures and temperatures of formation of diamond based on thermobarometry of chromian diopside inclusions. Can. Mineral. 40, 871-884.

Nimis, P., Taylor, W.R., 2000. Single clinopyroxene thermobarometry for garnet peridotites. Part I. Calibration and testing of a Cr-in-Cpx barometer and an enstatite-in-Cpx thermometer. Contrib. Mineral. Petrol. 139, 541-554.

Shimizu, N., Pokhilenko, N.P., Boyd, F.R., Pearson, D.G., 1997. Geochemical characteristics of mantle xenoliths from Udachnaya kimberlite pipe. Russian Geol. Geophys. 38, 205-217.

Sobolev, N.V., Kuznetsova, I.K., Zyuzin, N.I., 1968. Petrology of grospydite xenoliths from the Zagadochnaya kimberlite pipe in Yakutia. J. Petrology 9, 253-280.
Sobolev, N.V., Lavrent'ev, Y.G., Pokhilenko, N.P., Usova, L.V., 1973. Chrome-rich garnets from the kimberlites of Yakutia and their paragenesis. Contrib. Mineral. Petrol. 40, 39-52.

Sobolev, V.N., Taylor, L.A., Snyder, G.A., Sobolev, N.V., Pokhilenko, N.P., Kharkiv, A.D., 1997. A unique metasomatized peridotite xenolith from the Mir kimberlite, Siberian Platform. Russian Geol. Geophys. $38,218-228$.

Solovjeva, L.V., Egorov, K.N., Markova, M.E., Kharkiv, A.D., Popolitov, K.E., Barankevich, V.G., 1997. Mantle metasomatism and melting in mantle-derived xenoliths from the Udachnaya kimberlite; their possible relationship with diamond and kimberlite formation. Russian Geol. Geophys. 38, 182-204.

Vernieres, J., Godard, M., Bodinier, J.-L., 1997. A plate model for the simulation of trace element fractionation during partial melting and magma transport in the Earth's upper mantle. J. Geophys. Res. 102, 2477124784.

Wang, W., Gasparik, T., 2001. Metasomatic clinopyroxene inclusions in diamond from the Liaoning province, China. Geochim. Cosmochim. Acta 65, 611-620.

Xu, X., O'Reilly, S.Y., Griffin, W.L., Zhou, X., (2000). Genesis of young lithospheric mantle in Southeastern China: an LAM-ICPMS trace element study. J. Petrol. 41, 111-148.

Yaxley, F.M., Crawford, A.J., Green, D.H., 1991. Evidence for carbonatite metasomatism in spinel peridotite xenoliths from western Victoria, Australia. Earth Planet. Sci. Let. 107, 305-317.

Zanetti, A., Vannucci, R., Bottazzi, P., Oberti, R., Ottolini, L., 1996. Infiltration metasomatism at Lherz as monitored by systematic ion-microprobe investigations close to a hornblendite vein. Chem. Geol. 134, 113-133.

Contact: P Nimis, Dipartimento di Mineralogia e Petrologia, Università di Padova, C.so Garibaldi 37, 35137 Padova, Italy, E-mail: paolo.nimis@unipd.it 